УДК 342.9

DOI https://doi.org/10.32844/2618-1258.2019.3-1.16

БУРЛАКА I.С.

\title{
ДО ХАРАКТЕРИСТИКИ ФОРМ ВЗАЕМОДІЇ \\ ДЕРЖАВНОЇ МІГРАЦІЙНОЇ СЛУЖБИ УКРАЇНИ ІЗ ПРАВООХОРОННИМИ ОРГАНАМИ У СФЕРІ ПРОТИДІЇ НЕЛЕГАЛЬНІЙ МІГРАЦІЇ
}

У статті, на основі аналізу наукових поглядів учених і норм чинного законодавства України, визначено та надано характеристику формам взаємодії Державної міграційної служби України із правоохоронними органами у сфері протидії нелегальній міграції. Констатовано, що кожна форма взаємодії має свої характерні особливості та виконує специфічні завдання в досліджуваній сфері суспільних відносин. Обгрунтовано, що саме форми взаємодії Державної міграційної служби України із правоохоронними органами у сфері протидії нелегальній міграції $\epsilon$ об'єктивним зовнішнім відображенням спільної діяльності окреслених суб'єктів. Наголошено, що під формою взаємодії варто розуміти зовнішній вираз взаємоузгодженої діяльності відповідних суб'єктів для досягнення конкретної мети та вирішення спільних завдань, що стоять перед ними в конкретній сфері суспільних відносин. Дане визначення можна застосувати і до взаємодії Державної міграційної служби України із правоохоронними органами у сфері протидії нелегальній (незаконній) міграції. Визначено, що правова форма упорядковує відповідні відносини, дозволяє зіставляти поведінку зі встановленими зразками, вносить у життя нормативні початки, сприяє організованості і порядку, націлює суб'єктів права на найбільш раціональну поведінку і дії. Зроблено висновок, що взаємодія Державної міграційної служби України із правоохоронними органами у сфері протидії нелегальній (незаконній) міграції відображена у великій кількості форм, які, на нашу думку, можуть мати організаційний та правовий характер. Підкреслимо, що кожна 3 окреслених нами форм взаємодії доповнює одна одну та не може існувати відокремлено, адже, наприклад, не можна створити спільний нормативно-правовий акт або запропонувати відповідні зміни до чинного законодавства без попереднього обміну оперативною й іншою інформацією. Втім, зазначене не виключає той факт, що кожна форма взаємодії має свої характерні особливості та виконує специфічні завдання в досліджуваній сфері суспільних відносин. Тож, форми взаємодії Державної міграційної служби України із правоохоронними органами у сфері протидії нелегальній міграції є об'єктивним зовнішнім відображенням спільної діяльності окреслених суб'єктів.

Ключові слова: форма, правова форма, взаємодія, Державна міграчійна служба, правоохоронні органи, протидія, нелегальна міграчія.

In the article, based on the analysis of scientific views of scientists and norms of the current legislation of Ukraine, the forms of interaction of the State Migration Service of Ukraine with law enforcement agencies in the sphere of combating illegal migration are defined and given. It is stated that each form of interaction has its own peculiar features and fulfills specific tasks in the researched sphere of social relations. It is substantiated that the forms of interaction of the State Migration Service of Ukraine with law enforcement agencies in the area of combating illegal migration is an objective external reflection of the joint activity of these entities. It is emphasized that the form of interaction should be understood as the external expression of the co-ordinated activity of the respective subjects in order to achieve a specific goal and to solve common tasks that they face in a specific field of public relations. This definition can also be applied to the interaction of the State Migration Service of Ukraine with law enforcement agencies in the area of combating illegal (illegal) migration. It is determined that the legal form regulates the

(C) БУРЛАКА І.С. - здобувач (Науково-дослідний інститут публічного права) 
relations, allows to compare the behavior with the established models, brings to life the normative beginnings, promotes the organization and order, directs the subjects of the right to the most rational behavior and actions. It is concluded that the interaction of the State Migration Service of Ukraine with law enforcement agencies in the area of combating illegal (illegal) migration is reflected in a large number of forms that, in our opinion, can be organizational and legal in nature. We emphasize that each of the forms of interaction outlined by us is complementary and cannot exist separately, for example, it is not possible to create a common legal act, or to propose corresponding changes to the current legislation without first exchanging operational and other information. However, this does not exclude the fact that each form of interaction has its own peculiar features and fulfills specific tasks in the investigated sphere of social relations. Therefore, the forms of interaction of the State Migration Service of Ukraine with law enforcement agencies in the area of combating illegal migration is an objective external reflection of the joint activity of these entities.

Key words: form, legal form, interaction, State Migration Service, law enforcement, counteraction, illegal migration.

Вступ. Світова економічна криза, проведення бойових дій в різних кінцях світу, нестабільна політична ситуація тощо призвели до постійного зростання кількості нелегальних мігрантів. У зв'язку із цим в останні роки європейські країни посилили внутрішній нагляд і контроль за нелегальними мігрантами. Політичні світові інновації були спрямовані передусім на контроль, виявлення і навіть повторну ідентифікацію нелегальних мігрантів, які оселилися в їхніх межах. Варто зазначити, що сьогодні українська держава також досить багато уваги приділяє проблемі незаконної міграції, однак, намагаючись охопити велику кількість проблемних аспектів, і законодавець, і науковці залишили поза увагою необхідність забезпечення ефективної взаємодії органів державної влади в даній сфері, зокрема Державної міграційної служби (далі - ДМС) України із правоохоронними органами. Така взаємодія є складним та багатоаспектним явищем, реалізація якого передбачає використання сукупності різноманітних форм, вивчення яких має велике як теоретичне, так і практичне значення.

Окремі проблемні питання діяльності Державної міграційної служби України у своїх наукових дослідженнях розглядали: В.В. Новіков, Н.М. Ткачова, Р.А. Мартьянова, С.В. Слінько, Є.В. Погорелов, В.В. Шейбут, В.М. Снігур, Д.Б. Муратова, Я.І. Соловій, Ю.В. Александров, А.П. Гель, С.В. Ківалов, Л.О. Курій, О.В. Ткаченко та багато інших. Однак, незважаючи на чималу кількість наукових розробок, у юридичній літературі відсутні комплексні дослідження, присвячені проблемі взаємодії ДМС із правоохоронними органами, зокрема це стосується форм здійснення такої спільної діяльності.

Постановка завдання. Мета статті - визначити та дати характеристику формам взаємодії Державної міграційної служби України із правоохоронними органами у сфері протидії нелегальній міграції

Результати дослідження. У найбільш загальному та спрощеному розумінні форма - це будь-яке зовнішнє вираження певної діяльності. Поняття «форма» - це філософська категорія, розглядається філософією в єдності зі «змістом», водночас перше визначається насамперед як зовнішній контур, зовнішній вид предмета, зовнішнє вираження якого-небудь змісту [1, с. 489; 2]. У «Філософському словнику» І.Т. Фролова зазначається, що дана категорія вживається для відображення внутрішньої організації змісту, і в цьому значенні проблематика форми набуває подальшого розвитку в понятті структури [3, с. 519-520]. В.О. Якушин на підставі аналізу філософських джерел дійшов висновку, що категорія «форма» у філософії тлумачиться двояко. 3 одного боку, їі розкривають як спосіб вираження й існування змісту, а з іншого - як зовнішній вигляд предмета з межами й обрисами. У першому аспекті форма - це внутрішня компоновка, структура змісту в рамках якогось предмета. Відповідно до другого трактування, форма - це прояв змісту зовні, то, за допомогою чого один зміст може межувати з іншим у просторовому вимірі [4, c. 32].

Поняття «форма» активно використовується в теорії управління. Так, Г.В. Атаманчук зазначає, що форми управлінської діяльності являють собою зовнішні, постійно і типізовано фіксовані вираження (прояви) практичної активності державних органів щодо формування та реалізації управлінських цілей і функцій та забезпечення їхньої життєдіяльності [5, с. 171-172]. Д.Н. Батрах доводить, що форма управління - це зовнішнє вираження змісту управління, межі конкретних управлінських дій, учинених безпосередньо державними органами чи органами міс- 
цевого самоврядування, які специфічним чином розкривають зміст управлінської діяльності, самого управлінського впливу [6, с. 362].

3 погляду права, як пишуть В.М. Горшеньов та І.Б. Шахов, правова форма - це специфічна організаційна форма діяльності органів держави, посадових осіб та інших уповноважених суб'єктів, що: по-перше, здійснюється на основі найсуворішого дотримання вимог закону й інших нормативних актів; по-друге, іiі результати завжди спричиняють визначені наслідки, що мають юридичне значення або пов'язані з їх настанням. Зазначені два моменти виступають в органічній єдності і $є$ головними визначальними властивостями, а у своїй сукупності кваліфікують кожну організаційну форму діяльності як правову [7]. Правова форма, як зауважує А.О. Мовчан, - це інструмент оптимального вирішення поставлених практичних завдань. Вона упорядковує відповідні відносини, дозволяє зіставляти поведінку зі встановленими зразками, вносить у життя нормативні початки, сприяє організованості і порядку, націлює суб'єктів права на найбільш раціональну поведінку і дії $[8$, с. 86]. Як категорія теорії права правова форма характеризується загальністю й абстрактністю. Правові форми являють собою уособлені групи норм, що мають нормативне вираження у виді окремих утворень, юридичних режимів, які у практичній діяльності набувають стійкості і сталості [9, с. 222]. В.С. Шестак переконливо доводить, що правова форма діяльності - це організаційно-управлінська форма функціонування уповноважених на те суб'єктів, яка зв'язана зі здійсненням юридично значущих дій у порядку, визначеному законом, сутність правової форми діяльності держави полягає в тому, що вона заснована на приписах права та завжди спричиняє настання певних правових наслідків [10, с. 60].

Таким чином, незалежно від сфери суспільних відносин, під формою взаємодії варто розуміти зовнішній вираз взаємоузгодженої діяльності відповідних суб'єктів для досягнення конкретної мети та вирішення спільних завдань, що стоять перед ними в конкретній сфері суспільних відносин. Дане визначення, на наше переконання, можна застосувати і до взаємодії Державної міграційної служби України із правоохоронними органами у сфері протидії нелегальній (незаконній) міграції. Тож, до форм взаємодії окреслених органів державної влади у сфері протидії незаконній міграції варто віднести такі, як:

- спільна нормотворча діяльність. Взагалі нормотворчість, на думку Н.Ф. Лати, можна охарактеризувати як специфічну діяльність держави, в особі спеціально уповноважених на це владних суб' єктів, спрямовану на нормативне закріплення суспільних потреб й інтересів та забезпечення належних умов для реалізації прав і свобод громадян та їх ефективного захисту, яка здійснюється шляхом створення системи внутрішньо узгоджених нормативно-правових актів із метою підвищення ефективності регулювання суспільних відносин в Україні [11, с. 18]. Отже, спільна нормотворча діяльність Державної міграційної служби України із правоохоронними органами у сфері протидії нелегальній (незаконній) міграції передбачає створення ними в межах їхніх повноважень підзаконних нормативно-правових актів, які: а) спрямовуються на підвищення якості й ефективності взаємодії між цими суб'єктами (наприклад, Порядок взаємодії Державної міграційної служби України та Державної податкової служби України під час перевірки достовірності реєстраційного номера облікової картки платника податків або серії та номера паспорта фізичної особи, яка звернулася за оформленням паспорта громадянина України для виїзду за кордон, та ін.); б) спрямовані на покращення стану протидії нелегальній (незаконній) міграції. Спільна нормотворчість дає можливість суб'єктам, що взаємодіють, створити відповідне правове поле для здійснення їхньої подальшої спільної діяльності, що апріорі має велике теоретичне та практичне значення;

- розроблення рекомендацій та пропозицій з удосконалення законодавства, яке визначає правові засади здійснення взаємодії між ДМС і правоохоронними органами. Варто зазначити, що взагалі розвиток, зміна і доповнення законодавства зумовлені розвитком і зміною суспільних відносин, потребами й інтересами суспільства, потребами юридичної практики. Необхідність внесення змін та доповнень у нормативно-правові акти зумовлена саме цими обставинами. Внесення невиправданих змін, тобто таких, які не відповідають потребам суспільного розвитку і приводять до «інфляції» законодавства, не $\epsilon$ його вдосконаленням. Інакше кажучи, не всі зміни і доповнення законодавства $є$ його вдосконаленням. Крім того, удосконалення законодавства це, по суті, діяльність із постійного підтримання його якісного стану, тобто якості його змісту і форми. Це пов'язано з тим, що тільки в такому стані законодавство здатне забезпечити ефективне регулювання суспільних відносин [12, с. 12]. Дана форма взаємодії: по-перше, має велике значення для вдосконалення якості й ефективності взаємодії ДМС із правоохоронними органами в досліджуваній сфері; по-друге, апріорі дозволяє доповнити чинне законодавство нормами, які сприяють якісному покращенню стану протидії нелегальній (незаконній) міграції;

- проведення спільних перевірок підконтрольних об'єктів. Так, відповідно до Положення про Державну міграційну службу України від 20 серпня 2014 р. № 360, ДМС наділена 
повноваженнями ініціювати проведення спільних перевірок із правоохоронними органами й іншими центральними органами виконавчої влади в межах повноважень, передбачених законом [13], яким, до речі, дане відомство користується досить регулярно. Так, у червні 2019 р. співробітники Управління Державної міграційної служби в Запорізькій області спільно із працівниками ГУНП області, відділу організації запобігання нелегальній міграції Управління спільно із оперативними працівниками ОРУ АЧРУ, мобільної застави Бердянського прикордонного загону, із залученням батальйону поліції особливого призначення провели виїзну позапланову перевірку щодо виявлення іноземних громадян, які перебувають на території нашої держави з порушенням законодавства. Перевірка тривала в Кам'янсько-Дніпровському районі області на великій торговій площадці біля села Водяне, де розташований ринок оптово-роздрібної торгівлі та перебуває велика кількість іноземців, які займаються купівлею овочів та фруктів. Усього на законність перебування у країні було перевірено більше 300 осіб, сто з яких іноземці. За результатом роботи виявлено 2 нелегальних мігранти - громадяни Вірменії й Азербайджану. Останній перебував на території України без документів на право проживання та вчасно не покинув країну. Громадянин Вірменії, намагаючись уникнути адміністративної відповідальності та ввести співробітників міграційної служби в оману, назвався ім'ям свого знайомого, який має посвідку на постійне проживання в Україні. Працівниками відділу організації запобігання нелегальній міграції Управління спільно з оперативними працівниками ОРУ АЧРУ були проведені всі необхідні оперативні дії для з'ясування особи іноземця та встановлення його законності перебування [14]. Таких перевірок протягом року відбувається чимало практично в усіх регіонах нашої країни. Переконані, що проведення таких спільних перевірок важливе з погляду протидії нелегальній міграції в Україні;

- проведення спільних конференцій, розроблення науково-методичних рекомендацій.

Конференція - це діловий захід, метою якого є фахове обговорення актуальних проблем. Під час проведення конференції учасники активно обмінюються досвідом, формулюють головні тези і підбивають підсумки обговорень [15]. Так, у середині серпня 2019 р. в Обласному управлінні Державної міграційної служби Житомирщини відбулась Конференція трудового колективу, на яку прибули делегати всіх територіальних підрозділів та апарату УДМС. Дана Конференція мала на меті внесення змін до Правил внутрішнього розпорядку, які були викликані змінами структури та штатного розпису Управління, а також змінами законодавства. У зв'язку зі змінами назв районів області внесені зміни і в назви відповідних територіальних підрозділів міграційної служби Житомирщини. На Конференції розглянуті й інші нагальні питання працівників УДМС в області, про що свідчить протокол засідання [16]. Отже, проведення спільних конференцій - це така форма взаємодії ДМС із правоохоронними органами, яка дозволяє працівникам відповідних відомств обмінятись практичним досвідом, висловити свою думку щодо подальшого розвитку сфери протидії нелегальній (незаконній) міграції тощо. В Методична рекомендація являє собою науково обгрунтовану пораду про найбільш доцільний спосіб дій суб'єктів взаємодії в тій чи іншій типовій ситуації [17]. Іхня наявність дозволяє мінімізувати ризики щодо вчинення неправомірних та/або неправильних дій одного з учасників взаємодії;

- розроблення і реалізація спільних заходів щодо попередження правопорушень міграційного законодавства України. У найбільш загальному розумінні попередження правопорушень це здійснення економічних, політичних, ідеологічних, виховних, правових та інших заходів із протидії злочинності; це діяльність із виявлення й усунення причин злочинності в міграційній сфері, конкретних злочинів, із недопущення завершення злочинів на різних етапах розвитку злочинної поведінки [18; 19, с. 327]. Розроблення і реалізація спільних заходів як форма взаємодії Державної міграційної служби України із правоохоронними органами у сфері протидії нелегальній (незаконній) міграції дозволяє суб'єктам такої взаємодії більш комплексно підійти до вирішення наявних проблем у досліджуваній галузі, урахувати специфіку роботи кожного окремого органу в цій сфері тощо. Усе це у своїй сукупності дозволяє налагодити більш якісну взаємодію та проводити більш ефективні заходи щодо протидії незаконній міграції в Україні;

- обмін оперативною та поточною інформацією про стан протидії нелегальній (незаконній) міграції в Україні. Так, оперативна інформація використовується під час безпосереднього здійснення якихось заходів, а поточна - після їх завершення. Оперативна інформація використовується для оперативного регулювання процесів і діяльності в разі виникнення негативних відхилень від запланованих результатів. Поточна інформація узагальнює результати такої діяльності уповноважених органів та їхніх підрозділів за звітні періоди протягом календарного року (місяця, кварталу). Вона відбивається у звітності і використовується для контролю виконання планів, дослідження чинників, що негативно впливають на результати діяльності ДМС і правоохоронних органів [20]. Тож, сутність даної форми взаємодії Державної міграційної служби України із правоохоронними органами в досліджуваній сфері полягає в тому, що дані органи державної влади 
повинні постійно здійснювати обмін інформацією, яка їм стає доступною. Зазначене дозволяє більш оперативно виявляти проблеми в галузі незаконної міграції та швидко ухвалювати всі необхідні управлінські рішення.

Висновки. Отже, взаємодія Державної міграційної служби України із правоохоронними органами у сфері протидії нелегальній (незаконній) міграції знаходить своє відображення у великій кількості форм, які, на нашу думку, можуть мати організаційний та правовий характер. Зауважимо, що кожна з окреслених нами форм взаємодії доповнює одна одну та не може існувати відокремлено, адже, наприклад, не можна створити спільний нормативно-правовий акт або запропонувати відповідні зміни до чинного законодавства без попереднього обміну оперативною й іншою інформацією. Але зазначене не виключає той факт, що кожна форма взаємодії має свої характерні особливості та виконує специфічні завдання в досліджуваній сфері суспільних відносин. Тож, форми взаємодії ДМС із правоохоронними органами у сфері протидії нелегальній міграції є об'єктивним зовнішнім відображенням спільної діяльності окреслених суб'єктів.

\section{Список використаних джерел:}

1. Философский энциклопедический словарь / сост.: Е.Ф. Губский, Г.В. Кораблёва, В.А. Лутченко. Москва : Инфра-М, 1998. 576 с.

2. Шаповал В.Д. Конституційно-правовий статус сільського, селищного, міського голови в Україні : дис. ... канд. юрид. наук: 12.00.02. Київ, 2009. 220 с.

3. Философский словарь / под ред. И.Т. Фролова. 7 изд., перераб. и доп. Москва : Республика, 2001, 719 с.

4. Якушин В.А. Проблемы субъективного вменения в уголовном праве : автореф. дис. ... докт. юрид. наук: 12.00.08. Москва : МГУ, 1998. 391 с.

5. Советское административное право / под ред. В.М. Манохина. Москва : Юрид. лит., 1977. $544 \mathrm{c}$.

6. Бахрах Д.Н., Россинский Б.В., Старилов Ю.Н. Административное право : учебник для вузов. 3-е изд. пересмотр. и доп. Москва : Норма, 2007. 816 с.

7. Горшенев В.М., Шахов И.Б. Контроль как правовая форма деятельности. Москва : Юрид. лит., 1987. С. 36-37.

8. Мовчан А.О. Правове регулювання відносин із добору кадрів у ринкових умовах : дис. ... канд. юрид. наук: 12.00.05. Харків, 2009. 201 с.

9. Алексеев С.С. Общая теория права : в 2-х т. Москва : Юрид. лит., 1982. Т. 2. 360 с.

10. Шестак В.С. Державний контроль в сучасній Україні (теоретико-правові питання) : дис. ... канд. юрид. наук: 12.00.01. Харків, 2002. 195 с.

11. Лата Н.Ф. Адміністративно-правове регулювання нормотвор-чої діяльності органів виконавчої влади : дис. ... канд.. юрид. наук: 12.00.07. Київ, 2004. 198 с.

12. Погорелов С.В. Кодифікаційна діяльність в правовій системі України (загальнотеоретичний аспект) : дис. ... канд. юрид. наук: 12.00.01. Харків, 2000. 167 с.

13. Про затвердження Положення про Державну міграційну службу України : постанова Кабінету Міністрів України від 20 серпня 2014 р. № 360. URL: https://zakon.rada.gov.ua/laws/ show/360-2014-ח/conv.

14. В Запорізькій області провели рейд щодо виявлення порушників міграційного законодавства. Офіційний вебсайт Держсавної міграційної служби Украӥни. URL: https://dmsu.gov.ua/news/region/ v-zaporizkij-oblasti-proveli-rejd-shhodo-viyavlennya-porushnikiv-migraczijnogo-zakonodavstva.html.

15. Закордонний візит: правила поведінки : посібник для працівників судової системи / О.В. Какауліна та ін. Київ, 2010. 40 с.

16. Конференція трудового колективу державних службовців відбулась в Управлінні міграційної служби Житомирщини. Офіиійний вебсайт Державної міграційної служби Украӥни. URL: https://dmsu.gov.ua/news/region/5313.html.

17. Ищенко Е.П., Топорков А.А. Криминалистика : учебник / под ред. Е.П. Ищенко. Москва : Юрид. фирма «Контракт» ; Инфра-М, 2005. 483 с.

18. Алексеев А.И., Герасимов С.И., Сухарев А.Я. Криминологическая профилактика: теория, опыт, проблемы : монография. Москва : Норма, 2001. С. 1-26.

19. Криминология : учебник для юридических вузов / под общей ред. А.И. Долговой. Москва : Норма-Инфра, 1999. С. 324-338.

20. Офісний менеджмент : навчальний посібник / Л.І. Скібіцька та ін. Київ : Центр учбової літератури, 2014. $616 \mathrm{c}$. 